\title{
Translation Technology in English Studies Within the System of Higher Education in Poland
}

\author{
Michał Organ ${ }^{1}$ \\ ${ }^{1}$ Institute of Neophilology, University of Rzeszów, Poland \\ Correspondence: Michał Organ, Institute of Neophilology, University of Rzeszów, Rzeszów, Al. mjr. W. \\ Kopisto 2 B, 35-315 Rzeszów, Poland. E-mail: michal.organ@gmail.com
}

Received: April 22, 2021

Accepted: May 30, $2021 \quad$ Online Published: June 7, 2021

doi:10.5539/ijel.v11n4p1

URL: https://doi.org/10.5539/ijel.v11n4p1

\begin{abstract}
The study is focused on translation technology within the system of higher education in Poland, specifically English Studies offering translation specialization at BA and MA level, as well as postgraduate studies aimed at translators of English. The conducted analysis of translation curricula of Polish universities investigates the presence of courses devoted to the use of translation technology and seeks to determine whether such courses are offered at a given level of higher education, where in the system most of the courses are placed, and when they are mostly organized. First, however, a brief overview of different aspects determining the inclusion of translation technology in curricula are discussed. Here, the main stress is placed on its importance for the translation markets, the skills and knowledge obtained by students entering the market which are desired by translation agencies, elements affecting the selection of given translation software, the necessary infrastructure to run such courses, the costs of the programmes, 'human resources', the policies of universities, etc. The short discussion is followed by an analysis of the available courses, with each section devoted to one of the levels of the Polish higher education system, namely BA, MA and postgraduate studies. The courses within each level are briefly compared to provide some general tendencies for each type of studies. The final, concluding part of the study summarizes the results and stresses the need for further introduction of translation technology into translation curricula.
\end{abstract}

Keywords: translation technology, CAT tools, translation training, English studies, translation studies

\section{Introduction}

Since the advent of computers, followed by their gradual 'conquest' of different aspects of human life, contemporary proliferation, popularity and even universality, technology has revolutionized almost all domains of professional work, including translation. Today, it is difficult to imagine a translator performing his or her duties without the use of any computer software, starting with the very contact with clients, via text processors, to a whole plethora of other programs, including specialized computer assisted translation (CAT) tools. The impact of technology should therefore be reflected in the process of teaching translation and the education of future translators, so that universities, their research and teaching staff are better able to meet the demands of the rapidly developing market and equip students with the necessary knowledge and skills, including the use of specialized translation software. Nevertheless, their application in the translation curricula offered by universities and other higher education institutions is inextricably linked with varying preferences and different attitudes towards their very inclusion. Here, the issues connected with the proper selection of translation software (including their type, number, availability, advancement level etc.), the scope of knowledge of modern technology and the assignment of translation trainers and teachers adequately prepared to conduct such classes would be some of the basic elements determining 'whether', 'where' and 'when' such a course should be organized within the system of higher education devised for translators.

This study will predominantly address the very presence and actual placement of translation software in the curricula proposed by selected Polish universities offering a translation specialization in English Studies. The analysis is divided into three areas representing distinct tiers of the higher education system in Poland, namely BA studies, MA studies and postgraduate studies, in each of the 'levels' translation software courses are noted and then compared in terms of their placement in the translation curricula, the number of hours devoted to the issue, the type of classes, etc. First, however, some general aspects and specificity of teaching translation 
technology are briefly discussed to provide an adequate introductory overview of the different factors that may influence the placement of such courses into the translation curricula. Additionally, the Polish university education realia and its 'specificity', especially some selected issues affecting the local educational system, are also concisely mentioned to provide the necessary background for the research and make the results more meaningful to the reader.

The study offers a glimpse into the current state of teaching translation technology in Poland and might serve as reference material in any further research encompassing investigation concentrated on the employment of translation software at Polish universities. Similarly, the data might be used to provide a wider comparison of translation curricula offered by other foreign educational institutions to study the differences and similarities observed and to 'measure' the level of their technologization, etc.

\section{Teaching the Use of Translation Software}

The emergence of translation technology has gradually altered the market, since the middle of the nineties new software has gained steadily increasing popularity, the impact of which on work and realities was soon recognized by scholars calling for their inclusion in the translation curricula offered by universities and other higher education institutes, and adjusting the courses to the needs of the changing realities of translators' work (for instance Clark, 1994, p. 308). This view is commonly shared by other scholars for whom the integration of translation technologies stands for enhanced possibilities for practitioners of translation, especially in terms of their future professional careers and work outside of 'academia' (among others Clark, Rothwell, \& Shuttleworth, 2002; Bowker \& Marshman, 2010; Kenny, 2007). However, the presence of translation technology in translation training curricula not only gives students opportunities to gain employment but also establishes a convenient 'medium' for a wide range of research encompassing different aspects of Translation Studies, including the way translation should be taught, the cooperation between software and translators, the evaluation of applied technical solutions, the evolution of specialized software, the impact of programmes on the work of translators, etc. (for a detailed overview of potential areas of research see Kenny, 1999).

The long-lasting and heated debate over the inclusion of translation software in the system of translators' education frequently points out that training in the use of translation tools enables universities to maintain contact with the realities of the translation market, while attempts to minimize or neglect its importance may be harmful to the practical side of the translation curriculum and consequently will lead to the marginalization of university education devised for translators (Kingscott, 1996, p. 295). The practicality mentioned is especially vital for students wishing to continue their translation career after graduation. The research conducted by Kenny (1999, p. 79) indicates that students who completed a course devoted to CAT tools are far better prepared to meet the standards of the market, especially in terms of localization and faster delivery of target texts for translation agencies and other institutions (for the importance of teaching translation technology and its impact on localization see Schaler, 1998, p. 155). Translation bureaus, representing the 'translation industry', also emphasize the skills and knowledge desired or expected from graduates of translation acquired during translation courses. The OPTIMALE project (Optimising Professional Translator Training in a Multilingual Europe) investigated agencies and underlined some of the competencies related to mastering translation technology. According to the survey conducted by Garcés and Toudic (2015, pp. 192-193), 69\% of the respondents declared that the ability to extract and manage terminology is one of the basic skills demanded from potential workers. Similarly, proficiency in the use of translation memory systems is one of the most desired abilities as $76 \%$ of those polled consider it essential or important. $73 \%$ of respondents also view processing files and converting them into different formats etc. as an important skill (for further data see Garcés \& Toudic, 2015). The European Master's in Translation, a partnership project between the European Commission and higher education institutions offering MA level translation curricula, enumerated, among other qualities, the computer-related skills which each graduate should possess, for instance, they should be able to: freely use applications and search engines to look for desired information; apply programmes to analyze a language corpus; import terminology from different databases; process, convert and deliver texts in various formats for the needs of different devices and programmes; operate CAT tools and other software delivering machine translation; understand their possibilities, limitations, use and functionality; operate various translation programs and be prepared to use their new and updated versions; etc. (Toudic \& Krause, 2017, p. 9).

The data mentioned only superficially and selectively outline some of the aspects encompassed with translation technology, but noticeably a relatively high ratio of 'desirable' skills is simultaneously connected with their diversity in terms of the tools or software needed to successfully fulfil different functions during the process of translation. The issue is reflected in the discussion concerning the very presence of different types of software, their introduction and scope in the translation curricula. Here, the opinions represent an almost bipolar tendency, 
in which more critical approaches stress the lack of proper experience and in-depth knowledge of translation adepts to enable them to adequately evaluate the overall usability and combine with it the advantages and disadvantages of selected tools (for instance see Szwed, 2017; Dillon \& Fraser, 2006, p. 69). The criticism also concentrates on the naive unquestioning confidence of novices in the possibilities of software, especially the expectation of 'prime quality' of the generated target texts, and students' general tendency to expose the lack of common-sense evaluation of the acquired translation results (Bowker, 2005, p. 19; Zwierzchoń-Grabowska, 2019). Further implications for the curricula are combined with the focus of translation technology courses, whether more attention should be paid to mastering skills or deepening knowledge (O'Brien \& Kenny, 2001, p. 22). The courses that put 'skills' on a pedestal would likely concentrate on mastering the use and functions of some of the most popular programmes available on the market, allowing the students to meet some of the basic demands of job offers requiring the familiarization of some selected programmes. Conversely, the courses developing 'knowledge' present technology in more general terms to students with the aim of generating the ability to individually assess a tools' usefulness in a given translational task and to learn how to manage the operation of different tools on their own. Both strategies, however, may be easily linked together to form a truly multifaceted 'system' of teaching translation technology at different levels of university education. The key element in this multilevel approach is the presence of translation software in different courses adjusted to the knowledge and experience of students. This view is shared by Bowker (2015, p. 98), who claims that more general tools should be placed at earlier stages of translation curricula, whereas more advanced, complex programmes could be introduced at later stages of education. This strategy allows courses to gradually introduce different translation tools and prepare students for their use and, at the same time, the experience of a diversity of programs, with their numerous options and functions, as well as the hours of actual translation practice, make graduates better adjusted to the demands of the market and well-equipped members of the new generation of translators (Dillon \& Fraser, 2006, p. 75).

Scholarly debate focusing on different elements of teaching translation technology is strictly connected with more general, even mundane aspects, which, though usually omitted in the discussion, frequently decide on the shape and the very presence of translation technology in translation courses. Some of the factors include:

a) infrastructure - each course applying translation technology requires a classroom or a computer room with a workstation for each student and a similar post for the teacher. The seemingly obvious requirement proves, however, to be problematic in a certain environment in which the number of classrooms is limited; at Polish universities many buildings housing departments of humanities would need to be refurbished to include specialized computer rooms. Due to the limited number of classrooms, the management teams of departments are frequently unwilling to convert a given room into a modern computer lab claiming that its equipment would be unsuitable for the majority of other courses. The view that a given classroom may be easily converted into a computer room thanks to laptops does not take into consideration the difficulties arising from such a decision, including the additional time needed to place, run and finally put away mobile computers during each class, which consequently makes them disorganized and negatively affects the actual time spent on the practice of translation;

b) cost of the software - this issue was already observed by Somers (2003, p. 320). Most of the specialized programs devised for translators are rather expensive, in certain cases, their cost is even equal to the price of an average computer. Therefore, many educational institutions are not willing to pay on a one-off basis for the licences in a number adequate for a whole group of students. However, many producers of software, (for instance the companies offering memoQ, SDL Trados Studio and Déjà Vu) aware of the issue, offer special partnerships for universities that would like to teach future translators how to use their products. The programs of the academic partnership frequently include free use of the newest versions of the software for educational purposes. If however, a given university is not willing to pay for licences or sign up to any partnerships, teachers of translation may also turn to some programs that are offered free of charge, for instance OmegaT;

c) 'human resources' - may be understood as the lack of properly educated and prepared members of the teaching staff. Many members of academia graduated before the period in which translation technology became popular, more accessible to an average user and more useable in terms of the software output. Especially, some teachers are resistant to their use due to imperfect translations proposed by the technology (Bowker, 2002, p. 11) and a firm belief that traditional teaching of translation will not for a long time be supplanted by computers (Kingscott, 1996, p. 297). For many of them, the assumed 'technological barrier' hinders the attempts to learn how to work with the use of translation technology. The 'negation of technology' is at the same time combined with the fear that traditional classes may turn out to be obsolete (Haynes, 1998, p. 8). Apart from the apparent time-consuming and complicated nature of learning new forms of translation, some university teachers are more 
accustomed to teaching via more standardized and traditional forms and are unwilling to introduce any major changes, to 'leave the beaten track' of already practised patterns of teaching and prepare special packages of files needed in the process of translation (Marshman \& Bowker, 2012, p. 79). The inertia of teachers may be additionally strengthened by the fear of being less experienced in terms of technology and overall use of computers than the students. An insight into the vast availability of translation software, their different functions, versions and updates constitutes another problematic issue for teachers who might fear the regular necessity of modifying their classes and the need for continuous training in their operation (Samson, 2005, p. 103). An additional issue in Poland is combined with the preferences of university staff themselves, many of whom tend to focus on their research rather than on the education of students, as new scientific publications are the most important element for the periodic appraisals conducted by the university officials, and the actual teaching seems to be less important for their professional careers;

d) the policies of universities - this point is connected with the above-mentioned issue of 'human resources' and focuses on the organization and forms of employment common for the system of higher education. In Poland, many universities prefer to employ lecturers with at least a doctorate, who in many cases study translation mainly theoretically by conducting research in this field but not necessarily spending time on actual translation practice. On the other hand, translation practitioners, who on a daily basis apply translation technology in their work, prefer to focus on their jobs and cooperation with regular clients rather than to spend their time on freelance work for a university (Bogucki, 2009, p. 91).

The outlined specificity of factors stresses the presence of a whole plethora of elements determining the inclusion of specialized software in translators' training curricula. Even though the number of aspects influencing the decision is long and multilevel, the risk of neglecting the importance of technology for translation seems to contradict the main mission of higher education directed towards translators, namely to adequately and profoundly familiarize students with different aspects of translation and prepare them to enter the translation market. As stated by Kiraly (2000, p. 13), without such elements as the introduction of specialized software, traditional translation classes may only teach how to render texts, but students' translational competencies will be limited and not adjusted to the needs of modern markets dominated by technological advancements.

\section{Translation Software in the System of Higher Education in Poland}

The multifaceted inclusion of different aspects of technology into translation curricula may be seen as a prerequisite for reproducing the realities of actual translation practice and translators' real-life work environment. To at least signal the presence of a new era in the translation market, in 2020 more and more Polish universities provided classes devoted to the issue of translation software at BA and MA level of studies specializing in translation of English. Table 1 below serves as a brief overview of the courses offered by Polish universities teaching translators specializing in English (the list is limited to English Studies offered by the leading universities in Poland, Note 1). The object list of fields of study and offered courses is based on the ranking of English Studies in Poland published by the most renowned and influential educational portal, Perspektywy, backed up by curricula provided by individual academic units on their official webpages (Note 2). Table 1 includes a ranking list of studies, academic institutions offering courses devoted to the use of translation software included in the translation specialization, the level of studies, the semester in which a given course is organized, the actual name of the course, the number of hours covered during the course and the type of classes. 
Table 1. Translation software at BA and MA English studies offered by Polish universities

\begin{tabular}{|c|c|c|c|c|c|}
\hline University & Field of study, degree & Semester & Course & Number of hours & Type of classes \\
\hline $\begin{array}{l}\text { Adam Mickiewicz University in } \\
\text { Poznań } \\
\text { Department of English Studies }\end{array}$ & English Studies, MA & 1 & $\begin{array}{l}\text { Computer assisted } \\
\text { translation }\end{array}$ & 30 & workshop \\
\hline $\begin{array}{l}\text { SWPS University of Social } \\
\text { Sciences and Humanities } \\
\text { Department of Humanities and } \\
\text { Social Sciences }\end{array}$ & English Studies, MA & 2 & $\begin{array}{l}\text { Translation service } \\
\text { provision and CAT } \\
\text { tools }\end{array}$ & 30 & seminar \\
\hline $\begin{array}{l}\text { University of Łódź } \\
\text { Institute of English Studies }\end{array}$ & English Studies, BA & 3 and 4 & $\begin{array}{l}\text { The use of } \\
\text { computer and } \\
\text { digital tools in } \\
\text { translation }\end{array}$ & 60 & $\begin{array}{l}\text { introductory } \\
\text { seminar }\end{array}$ \\
\hline $\begin{array}{l}\text { University of Łódź } \\
\text { Institute of English Studies }\end{array}$ & English Studies, MA & 3 & $\begin{array}{l}\text { Computer assisted } \\
\text { translation }\end{array}$ & 30 & $\begin{array}{l}\text { introductory } \\
\text { seminar }\end{array}$ \\
\hline $\begin{array}{l}\text { University of Silesia } \\
\text { Department of Humanities }\end{array}$ & $\begin{array}{l}\text { English Studies, } \\
\text { MA }\end{array}$ & 2 & $\begin{array}{l}\text { Computer Assisted } \\
\text { Translation }\end{array}$ & 30 & workshop \\
\hline $\begin{array}{l}\text { University of Social Sciences in } \\
\text { Łódź }\end{array}$ & $\begin{array}{l}\text { English Studies } \\
\text { BA }\end{array}$ & 3 & $\begin{array}{l}\text { Translator's } \\
\text { workstation }\end{array}$ & 30 & workshop \\
\hline $\begin{array}{l}\text { Institute of Social } \\
\text { Communication and Pedagogy }\end{array}$ & & & & & \\
\hline $\begin{array}{l}\text { University of Social Sciences in } \\
\text { Łódź } \\
\text { Institute of Social } \\
\text { Communication and Pedagogy }\end{array}$ & $\begin{array}{l}\text { English Studies } \\
\text { MA }\end{array}$ & 1 & Translation tools & 30 & workshop \\
\hline $\begin{array}{l}\text { University of Gdańsk } \\
\text { Faculty of Languages }\end{array}$ & English Studies, BA & 1 & $\begin{array}{l}\text { Information } \\
\text { technology for } \\
\text { translators }\end{array}$ & 45 & workshop \\
\hline $\begin{array}{l}\text { University of Gdańsk } \\
\text { Faculty of Languages }\end{array}$ & English Studies, MA & 1 and 2 & $\begin{array}{l}\text { Translator's } \\
\text { workstation }\end{array}$ & 75 & $\begin{array}{l}\text { workshop }-60 \mathrm{~h} \\
\text { discussion } \\
\text { classes }-15 \mathrm{~h}\end{array}$ \\
\hline $\begin{array}{l}\text { Pedagogical University of } \\
\text { Cracow } \\
\text { Institute of English Studies }\end{array}$ & English Studies, MA & 1 & $\begin{array}{l}\text { Digital tools in } \\
\text { translation }\end{array}$ & 30 & $\begin{array}{l}\text { discussion } \\
\text { classes }\end{array}$ \\
\hline $\begin{array}{l}\text { Pedagogical University of } \\
\text { Cracow } \\
\text { Institute of English Studies }\end{array}$ & English Studies, MA & 2 & $\begin{array}{l}\text { Computer assisted } \\
\text { translation }\end{array}$ & 30 & workshop \\
\hline $\begin{array}{l}\text { Pedagogical University of } \\
\text { Cracow } \\
\text { Institute of English Studies }\end{array}$ & English Studies, MA & 3 & $\begin{array}{l}\text { Computer } \\
\text { technologies and } \\
\text { postedition }\end{array}$ & 30 & workshop \\
\hline $\begin{array}{l}\text { Vistula University in Warsaw } \\
\text { Department of Humanities }\end{array}$ & $\begin{array}{l}\text { English Studies } \\
\text { BA }\end{array}$ & 6 & $\begin{array}{l}\text { New Technologies } \\
\text { in Translation }\end{array}$ & 30 & workshop \\
\hline
\end{tabular}

\subsection{BA Studies}

The presence of translation technologies, mostly CAT tools, is noted in 8 out of 15 universities, that is in almost half of studies dedicated for translators. Only 4 courses devoted to the use of translation software are included in the translation curricula at the BA level, interestingly, if such a course is present at this level of studies, most of the universities also offer an additional course of CAT tools at the MA level. Here, only 1 university, namely Vistula University in Warsaw, limits such courses merely to the BA level. The number of hours dedicated to each of the courses differs significantly. 2 universities propose 30h of workshops; however, their organization differs: Translator's workstation at the University of Social Sciences in Łódź is placed in the 3rd semester of studies, whereas New Technologies in Translation at the Vistula University in Warsaw takes place in the 6th and final semester of BA studies. Noteworthy, neither course is limited to CAT tools sensu stricto; they rather serve as more general classes covering different aspects of modern technology, translation software and other computer programmes suitable for the current needs of translators. In both courses CAT tools are included in the curricula, they do not constitute the core of the classes, but they emphasize the very existence and usefulness of such software, and take a glimpse into their possibilities and utility in everyday translation duties. The University of Gdańsk specially altered and slightly extended the obligatory Information technology course, which has to be 
present in every BA curriculum offered in Poland, to make it more suitable and adjusted to the profile of English Studies, and especially the Translation specialization. Its Information technology for translators takes $45 \mathrm{~h}$ of workshops and is organized during the very first semester of BA studies. The decision to alter the course is commendable as it ensures that students at a very early stage of their translation education learn about different technological solutions facilitating the process of rendition, and have more time to practice their usefulness. Moreover, the inclusion of the subject at this stage allows them to apply the obtained knowledge and skills during other classes included in the curricula which help them master practical translation skills. Another example of an extended course is present at the University of Łódź, where The use of computer and digital tools in translation is a two-semester course organized in the second year of BA studies. Altogether $60 \mathrm{~h}$ of introductory seminars dedicated to modern technologies in translation at this level of studies propose a profound and multifaceted coverage of the subject, allowing students to master basic software used during everyday translation activities, as well as to learn about some more specific and specialized tools employed to conduct particular translational needs. The examples of the University of Gdańsk and the University of Łódź are especially interesting for students, as their offer of courses dedicated to CAT tools and modern technologies in translation are not limited solely to BA studies, their extended and more specific continuations are also included at the MA level of studies.

\subsection{MA Studies}

Special courses focusing on modern translation technologies are mostly organized at the MA level, with almost half of the analyzed universities proposing such classes for students of English Studies specializing in translation. All but one proposes a single course, only the Pedagogical University of Cracow has extended the use of computers in translation into almost the whole cycle of education, that is into three out of four semesters of MA studies. Nearly all of them offer a short $30 \mathrm{~h}$ course which is usually organized during the first year of studies, either in the first or the second semester; only the University of Łódź and one of three courses offered by the Pedagogical University of Cracow take place during the second year of studies in the third semester. The inclusion of such courses in translation curricula at early stages of education is particularly important for trainee translators, as the knowledge and skills obtained might prove to be especially useful during other classes, for instance, those focusing on the translation of specialized texts and involving gathering specialized terminology in term banks, etc. The organization of such courses during the first year of studies is also recommended, as students are obliged to do a practical translation work placement between the second and third semester, usually in a translation agency. In the majority of bureaus, translations are delivered via the use of CAT tools, and students are expected to know at least some basics of the most common translation software and be able to deliver simple renditions. Without some elementary experience with such programs, students may encounter certain difficulties in finding an agency willing to additionally spend their time teaching a student how to operate their software and perform basic translation tasks. Usually, courses last one semester, with only the University of Gdańsk offering extended classes; its Translator's workstation is an important element of the curricula during the first two semesters. The $75 \mathrm{~h}$-course is a composite of two types of classes, namely $60 \mathrm{~h}$ of workshops and $15 \mathrm{~h}$ of discussion classes. However, the first place belongs to the Pedagogical University of Cracow, where translation technologies are directly incorporated into three courses, each of them lasting 30h. During the first semester, students take part in discussion classes, Digital tools in translation, serving as an introduction to 'the world of translation software'. In the next semesters, curricula introduce two workshops, firstly Computer assisted translation, and subsequently Computer technologies and postedition. Here, translation technology is treated as a multifaceted phenomenon and its importance and practical application are gradually introduced, starting from a very general discussion, through a proper mastering of their basic use, to familiarization with some additional functions and options that help to review and optimize delivered texts. The desired strategy of providing computer software in translation curricula is followed differently by various universities, three of them, namely the University of Łódź, the University of Social Sciences in Łódź and the University of Gdańsk, propose such courses at both BA and MA levels of studies. The University of Gdańsk additionally extended both courses in terms of hours, altogether proposing $120 \mathrm{~h}$ of classes, similarly the University of Łódź offers $90 \mathrm{~h}$ of translation technologies in their curricula. The Pedagogical University of Cracow opted for a different model in which all three courses, lasting altogether $90 \mathrm{~h}$, are organized at the MA level of studies, without proposing any such classes at the BA level.

\subsection{Postgraduate Studies}

In the Polish system of higher education, additional courses of English translation are also included in the curricula of different postgraduate studies for translators. Such studies are usually available for graduates of at least BA studies. Depending on their profile, the requirements may differ, for instance, some general translation 
studies are open also for students who have not attended English Studies but have obtained language certificates such as the Certificate of Proficiency in English, whereas more specialized translation studies might be available only for the graduates of English Studies. Additionally, postgraduate studies are also differentiated by their aim, for instance, to provide necessary knowledge and skills needed to acquire the certificate of a sworn translator (Postgraduate studies for candidates for sworn translators at Adam Mickiewicz University in Poznań), and the level of translation experience, for instance, some introductory studies for people who had not practised translation before (Translation and interpreting at the University of Applied Sciences in Tarnów), and studies for more experienced translators wishing to master their skills, learn some new 'tricks of the trade' and adjust to the modern translation market (Postgraduate studies for specialized translators at Adam Mickiewicz University in Poznań). The list of selected postgraduate studies specializing in English translation that include a special course dedicated to modern translation technologies is presented in Table 2.

Table 2. Translation software in the system of postgraduate education in Poland

\begin{tabular}{|c|c|c|c|c|c|}
\hline University & Postgraduate studies & Semester & Course & Number of hours & Type of classes \\
\hline University of Warsaw & $\begin{array}{l}\text { Interdisciplinary postgraduate } \\
\text { studies in translation and } \\
\text { interpreting }\end{array}$ & 2 & $\begin{array}{l}\text { CAT translation } \\
\text { workshops }\end{array}$ & 20 & workshop \\
\hline Jagiellonian University & $\begin{array}{l}\text { Postgraduate studies for } \\
\text { translators - translation of } \\
\text { specialized texts }\end{array}$ & 1 & CAT tools & 20 & workshop \\
\hline Jagiellonian University & $\begin{array}{l}\text { Postgraduate studies for } \\
\text { translators - certified and } \\
\text { community translations }\end{array}$ & - & CAT tools & 20 & workshop \\
\hline $\begin{array}{l}\text { Adam Mickiewicz } \\
\text { University in Poznań }\end{array}$ & $\begin{array}{l}\text { Postgraduate studies for } \\
\text { specialized translators }\end{array}$ & - & $\begin{array}{l}\text { Information } \\
\text { technology for } \\
\text { translators }\end{array}$ & 12 & workshop \\
\hline $\begin{array}{l}\text { Adam Mickiewicz } \\
\text { University in Poznań }\end{array}$ & $\begin{array}{l}\text { Postgraduate studies for } \\
\text { candidates for sworn translators }\end{array}$ & 2 & $\begin{array}{l}\text { Computer assisted } \\
\text { translation }\end{array}$ & 18 & workshop \\
\hline University of Wrocław & $\begin{array}{l}\text { Translation podstgraduate } \\
\text { studies }\end{array}$ & - & $\begin{array}{l}\text { Computer assisted } \\
\text { translation }\end{array}$ & 16 & workshop \\
\hline University of Wrocław & $\begin{array}{l}\text { Language in certified } \\
\text { translation }\end{array}$ & 1 and 2 & $\begin{array}{l}\text { Computer tools in } \\
\text { the translation of } \\
\text { legal texts }\end{array}$ & 20 & workshop \\
\hline $\begin{array}{l}\text { Maria Curie-Skłodowska } \\
\text { University in Lublin }\end{array}$ & $\begin{array}{l}\text { Specialized and certified } \\
\text { translations }\end{array}$ & 2 & $\begin{array}{l}\text { The use of } \\
\text { computer tools in } \\
\text { translation }\end{array}$ & 8 & lecture \\
\hline $\begin{array}{l}\text { Kazimierz Wielki } \\
\text { University in Bydgoszcz }\end{array}$ & $\begin{array}{l}\text { Postgraduate studies for } \\
\text { translators of English }\end{array}$ & - & $\begin{array}{l}\text { Computer assisted } \\
\text { translation }\end{array}$ & 16 & workshop \\
\hline University of Łódź & $\begin{array}{l}\text { Postgraduate studies of } \\
\text { specialized translations }\end{array}$ & 2 & $\begin{array}{l}\text { Computer assisted } \\
\text { translation }\end{array}$ & $\begin{array}{l}20 \text { (16h of online } \\
\text { classes) }\end{array}$ & workshop \\
\hline $\begin{array}{l}\text { University of Applied } \\
\text { Sciences in Tarnów }\end{array}$ & Translation and interpreting & 1 and 2 & $\begin{array}{l}\text { Computer assisted } \\
\text { translation }\end{array}$ & 20 & workshop \\
\hline $\begin{array}{l}\text { WSB University in } \\
\text { Wrocław }\end{array}$ & $\begin{array}{l}\text { Postgraduate Studies of } \\
\text { specialized English translations }\end{array}$ & - & $\begin{array}{l}\text { The use of } \\
\text { computer tools in } \\
\text { translation }\end{array}$ & 12 & workshop \\
\hline
\end{tabular}

Regardless of their profile, the analyzed postgraduate studies tend to include at least a short course on CAT tools, ranging from $8 \mathrm{~h}$ to $20 \mathrm{~h}$ of classes. Typically, the courses organized in postgraduate studies are slightly shorter than at BA and MA studies, and 'normally' $20 \mathrm{~h}$ of classes may be treated as an equivalent of a $30 \mathrm{~h}$-course taking place at the first or the second level of the higher education system. Half of the analyzed classes last $20 \mathrm{~h}$, this amount of time is dedicated to translation technologies in 6 out of 12 studies; however, the courses offered by Adam Mickiewicz University in Poznan (18h), the University of Wrocław (16h) and the Kazimierz Wielki University in Bydgoszcz (16h) are only slightly shorter. The shortest course, namely The use of computer tools in translation, lasting only $8 \mathrm{~h}$ is offered by the Maria Curie-Skłodowska University in Lublin. When the type of classes is taken into consideration, all but one of the courses are conducted as workshops, only the shortest classes, offered by the Maria Curie-Skłodowska University in Lublin, are classified as lectures. The organization of the course is almost standardized, only the course of Computer assisted translation at the University of Łódź 
is almost entirely carried out as online classes (only $4 \mathrm{~h}$ out of the $20 \mathrm{~h}$-course are conducted traditionally in the classroom). The analysis of available curricula does not allow us to explicitly state when the course should take place, predominantly postgraduate courses in Poland are composed of two semesters. The data presented in Table 2 emphasize different strategies for organizing such classes, as the courses are organized either in the first (for instance the Jagiellonian University) or in the second semester (for instance Adam Mickiewicz University in Poznań) as well as during both semesters of studies (for instance the University of Wrocław) (Note 3). The placement of the classes in the appropriate semester of the studies might be adjusted to the desired profile of the potential students wishing to enrol for given studies, for instance, a profile based on the experience in translation of potential candidates. Postgraduate studies aimed at beginning translators or candidates who have not graduated from a translation specialization in their studies may place the classes in the second semester and focus on some fundamental aspects of translation, or divide them into both semesters to allow slightly slower but continuous 'contact' with modern translation technology. On the other hand, the postgraduate studies offered for practitioners and experienced translators wishing to master skills and update their knowledge may follow a different strategy and either place the course in the first semester or extend it into both semesters. This option allows students to enter the 'digital world' from the very beginning of their studies and employ the newly acquired skills during other courses devoted to practical aspects of translation.

The presence and popularity of such courses within very different postgraduate studies for translators indicate that there is a certain niche in the educational market and increased demand for qualified translators able to cooperate with agencies via specialized translation software. Simultaneously, the presence of CAT tools in the curricula is a chance for practitioners of translation to familiarize themselves with their possibilities, especially if their previous studies have not covered such elements or the time assigned to translation software was unsatisfactorily limited, for instance, they have graduated from their studies before the popularization of CAT tools, or if they attended a different specialization during their original studies. In this view, the course may be seen as a way of updating their knowledge and opening them up to new possibilities of modern technology.

\section{Conclusion}

Translation technology in English Studies offered by Polish universities is slowly but surely gaining popularity, and individual courses encompassing this scope of translators' education are present in each level of the Polish system of higher education. However, the analysis indicates that only a few of the best courses in English Studies for translators propose such courses, and their inclusion in the curricula follows different strategies. Out of all analyzed universities, only a few have decided to organize such a course in BA studies. If, however, they are present at this level, the same institutions tend to additionally provide more advanced courses of translation technology in their MA studies. Half of the courses present in the first level of higher education are extended in terms of hours, for instance, $45 \mathrm{~h}$ or $60 \mathrm{~h}$ when the average course devoted to different aspects of translation last $30 \mathrm{~h}$ at Polish universities. All of the courses of translation technology in BA studies are organized before the end of the second year of the translation specialization, this decision allows the students to be equipped with some useful skills and knowledge before they start their obligatory translation training in selected translation agencies. The courses present at this level are mostly introductory workshops covering selected, less advanced programmes and translation software. On the other hand, the translation curricula of MA studies include far more courses on translation technology, with almost half of the analyzed universities proposing such classes, predominantly devoted to CAT tools. On average, a typical course of CAT tools encompasses 30h of workshops organized during the first year of MA studies. The placement of the course during the first or the second semester of the studies may also be correlated with the second obligatory translation training which students need to undergo between the first and the second year of the translation training for MA studies. Noticeably, only two universities have extended their courses of translation technology, either only in terms of the number of hours devoted to the subject or both in terms of the overall number of classes and the introduction of additional, more specialized courses which gradually familiarize students with different types of software and their application. Graduates of English Studies may continue their education in translation thanks to various postgraduate courses. Interestingly, regardless of their specificity and thematic scope, many of them tend to include courses focusing on translation technology, predominantly devoted to CAT tools. The observable proliferation of such classes demonstrates the presence of an educational niche caused by a few factors, including the growing market demands for technologically-skilled translations, the increasing pace of translators' work and the desire of translators to update their knowledge and skills as well as to supplement their education in this field. The organization of such courses, in certain cases by educational institutions that do not offer similar classes in their BA or MA, is correlated with the nature of postgraduate studies, which in Poland tend to be more focused on 'translation practice' rather than on theoretical problems affecting Translation Studies. Postgraduate studies, as a 
paid form of education, are more adjusted to the actual needs or predicted 'desires' of candidates. The inclusion of such a course serves as a 'magnet', as most of the official web pages advertising the studies emphasize the presence of modern translation technology in their curricula.

The presented analysis briefly outlines the specificity of transition technology within the system of higher education in Poland, specifically English Studies aimed at translators. The study observes an overall need for the further introduction of additional courses into translation curricula of English Studies that do not provide such courses for their students, or they include them on only one of the levels of translators' education. The further introduction of translation technology should also be present within other courses of translation, not necessarily thematically limited to the technology itself, as their application during various specialized translation classes would allow the acquisition of proficiency in their actual use and understanding of their importance for the profession.

\section{References}

Adam Mickiewicz University in Poznań. (2021a). Curriculum of postgraduate studies. Retrieved April 21, 2021, from http://wa.amu.edu.pl/spkts/Program/Program.html

Adam Mickiewicz University in Poznań. (2021b). MA curriculum of English Studies. Retrieved April 21, 2021, from $\mathrm{http}: / /$ wa.amu.edu.pl/wa/pl/general_information_index

Atril. (2021). Academic partnership. Retrieved April 21, 2021, from https://atril.com/academic-partnership/

Bogucki, Ł. (2009). Computer Assisted Translation. Warszawa: Państwowe Wydawnictwo Naukowe.

Bowker, L. (2002). Computer-aided translation technology: A Practical introduction. Ottawa: University of Ottawa Press.

Bowker, L. (2005). Productivity vs Quality? A Pilot Study on the Impact of Translation Memory Systems. Localisation Focus, 4(1), 13-20.

Bowker, L. (2015). Computer-aided translation. Translator training. In C. Sin-wai (Ed.), The Routledge encyclopedia of translation technology (pp. 88-104). New York.

Bowker, L., \& Marshman, E. (2010). Toward a Model of Active and Situated Learning in the Teaching of Computer-aided Translation: Introducing the CERTT Project. Journal of Translation Studies, 13(1-2), 99-226.

Clark, R. (1994). Computer-assisted translation: The State of the art. In C. Dollerup \& A. Lindegaard (Eds.), Teaching translation and tnterpreting 2: Insights, aims, visions (pp. 301-308). Amsterdam \& Philadelphia: John Benjamins Publishing Company.

Clark, R., Rothwell, A., \& Shuttleworth, M. (2002). Integrating language technology into a postgraduate translation programme. In B. Maia, J. Haller \& M. Ulrych (Eds.), Training the language services provider for the new millennium (p. 63-70). Porto: University of Porto.

Dillon, S., \& Fraser, J. (2006). Translators and TM: An Investigation of Translators' Perceptions of Translation Memory Adoption. Machine Translation, 20(2), 67-79. https://doi.org/10.1007/s10590-006-9004-8

Garcés, C. V., \& Toudic, D. (2015). Technological Innovation and Translation. Training Translators in the EU for the 21 st century. Journal of English and Spanish Studies, 0, 183-202.

Haynes, C. (1998). Breaking down the language barriers. London: Aslib.

Jagiellonian University. (2021). Curriculum of postgraduate studies. Retrieved April 21, 2021, from https://przeklad.filg.uj.edu.pl/en_GB/studia-podyplomowe2

Kazimierz Wielki University in Bydgoszcz. (2021). Curriculum of postgraduate studies. Retrieved April 21, 2021, from http://www.tlumaczeukw.pl/p/przedmioty.html

Kenny, D. (1999). CAT Tools in an Academic Environment: What Are They Good For? Target, 11(1), 65-82. https://doi.org/10.1075/target.11.1.04ken

Kenny, D. (2007). Translation memories and parallel corpora: Challenges for the translation trainer. In D. Kenny \& K. Ryou (Eds.), Across boundaries: International perspectives on translation studies (pp. 192-208). Newcastle upon Tyne: Cambridge Scholars Publishing.

Kingscott, G. (1996). The Impact of technology and the implications for teaching. In C. Dollerup \& V. Appel (Eds.), Teaching translation and interpreting 3: New horizons (pp. 295-300). Amsterdam \& Philadelphia: John Benjamins Publishing Company. https://doi.org/10.1075/btl.16.38kin 
Kiraly, D. (2000). A Social constructivist approach to translator education. Manchester: St. Jerome Publishing.

Maria Curie-Skłodowska University in Lublin. (2021). Curriculum of postgraduate studies. Retrieved April 21, 2021, from https://www.umcs.pl/pl/wyszukiwarka-studiow,118,tlumaczenia-poswiadczone-i-specjalistyczne-jez-angiels ki-niemiecki-francuski-rosyjski-,22589.chtm

Marshman, E., \& Bowker, L. (2012). Translation technologies as seen through the eyes of educators and students: Harmonizing views with the help of a centralized teaching and learning resource. In S. Hubscher-Davidson \& M. Borodo (Eds.), Global trends in translator and interpreter training: Mediation and culture (pp. 69-95). London and New York: Continuum.

MemoQ. (2021). Academic partnership. Retrieved April 21, 2021, from https://www.memoq.com/services/academic-program

O’Brien, S., \& Kenny, D. (2001). In Dublin's Fair City: Teaching Translation Technology at Dublin City University. Language International, 13(5), 20-23.

OmegaT. (2021). Official webpage. Retrieved April 21, 2021, from https://omegat.org/

Pedagogical University of Cracow. (2021). MA curriculum of English Studies. Retrieved April 21, 2021, from https://anglistyka.up.krakow.pl/en/home-page/

Perspektywy ranking list of English Studies in Poland. (2020). Retrieved April 21, 2021, from http://ranking.perspektywy.pl/2020/ranking/ranking-kierunkow-studiow/kierunki-humanistyczne/filologia-a ngielska

Samson, R. (2005). Computer assisted translation. In M. Tennent (Ed.), Training for the new millennium: Pedagogies for translation and interpreting (pp. 101-126). Amsterdam and Philadelphia: John Benjamins Publishing Company. https://doi.org/10.1075/btl.60.11sam

Schaler, R. (1998). The Problem with machine translation. In L. Bowker, M. Cronin, D. Kenny \& J. Pearson (Eds.), Unity in diversity? Current trends in translation studies (pp. 151-156). Manchester: St. Jerome Publishing.

SDL Trados. (2021). Academic partnership. Retrieved April 21, 2021, from https://www.trados.com/education/

Somers, H. (2003). Machine translation in the classroom. In H. Somers (Ed.), Computers and translation (pp. 319-340). Amsterdam \& Philadelphia: John Benjamins Publishing Company. https://doi.org/10.1075/btl.35.20som

SWPS University of Social Sciences and Humanities. (2021). MA curriculum of English Studies. Retrieved April 21 , 2021, from https://english.swps.pl/academics/warsaw/ma-programs/english-studies?_ga=2.221537432.1222276988.161 6751598-281583282.1616751597

Szwed, M. (2017). Pitfalls of the Growing Popularity of CAT Tools in Translation Didactics. Linguodidactica, 21, 233-246. https://doi.org/10.15290/lingdid.2017.21.17

The University of Applied Sciences in Tarnów. (2021). Curriculum of postgraduate studies. Retrieved April 21, 2021, from https://pwsztar.edu.pl/uczelnia/studia-podyplomowe/tlumaczenia-pisemne/

The University of Gdańsk. (2021). MA curriculum of English Studies. Retrieved April 21, 2021, from https://en.fil.ug.edu.pl/

The University of Łódź. (2021a). Curriculum of postgraduate studies. Retrieved April 21, 2021, from http://translatoryka.uni.lodz.pl/psts.html

The University of Łódź. (2021b). MA curriculum of English Studies. Retrieved April 21, 2021, from http://anglistyka.uni.lodz.pl/studenci/programy-studiow/

The University of Silesia. (2021). MA curriculum of English Studies. Retrieved April 21, 2021, from https://informator.us.edu.pl/kierunki/W1-S2FA19.2020/5_3491

The University of Social Sciences in Łódź. (2021a). MA curriculum of English Studies. Retrieved April 21, 2021, from https://lodz.san.edu.pl/oferta/studia-ii-stopnia/filologia-angielska/o-kierunku

The University of Social Sciences in Łódź. (2021b). BA curriculum of English Studies. Retrieved April 21, 2021, from https://lodz.san.edu.pl/oferta/studia-i-stopnia/filologia-angielska/realizowane-przedmioty 
The University of Warsaw. (2021). Curriculum of postgraduate studies. Retrieved April 21, 2021, from https://www.ils.uw.edu.pl/en/postgraduate-studies/ipskt/

The University of Wrocław. (2021a). Curriculum of postgraduate studies. Retrieved April 21, 2021, from http://www.studiumprzekladu.uni.wroc.pl/index.php/informacje/program/

The University of Wrocław. (2021b). Curriculum of postgraduate studies. Retrieved April 21, 2021, from http://www.ifa.uni.wroc.pl/spajs/index.php/program-2/jezyk-w-przekladzie-poswiadczonym/

Toudic, D., \& Krause, A. (2017). European master's in translation. Competence framework 2017. European Commission. Retrieved from https://ec.europa.eu/info/resources-partners/european-masters-translation-emt/european-masters-translationemt-explained_en

Vistula University in Warsaw. (2021). BA curriculum of English Studies. Retrieved April 21, 2021, from https://www.vistula.edu.pl/kierunki-studiow/studia-i-stopnia/studia-licencjackie/filologia-angielska

WSB University in Wrocław. (2021). Curriculum of postgraduate studies. Retrieved April 21, 2021, from https://www.wsb.pl/wroclaw/studia-i-szkolenia/studia-podyplomowe/kierunki/podyplomowe-studia-ksztalc enia-tlumaczy-specjalistycznych-w-zakresie-jezyka-angielskiego/program-studiow

Zwierzchoń-Grabowska, E. (2019). Software in the work of beginner translators. Przestrzenie Przektadu, 3, 301-310.

\section{Notes}

Note 1. If a given university is not included in Table 1 it means that it does not offer courses devoted to translation technology, or the official webpage of a given educational institution does not inform about their inclusion in the curricula. Due to their individual specificity, the list does not include courses devoted to audiovisual translation, which is in the centre of analysis in a forthcoming study.

Note 2. The list of analyzed translation curricula is presented in the primary sources.

Note 3. However, almost half of the postgraduate studies have no information in their official curricula presented on the webpages of the given educational institution about when a given course will actually take place.

\section{Copyrights}

Copyright for this article is retained by the author, with first publication rights granted to the journal.

This is an open-access article distributed under the terms and conditions of the Creative Commons Attribution license (http://creativecommons.org/licenses/by/4.0/). 